\title{
Safety by design: engineers and entrepreneurs invent fire safety in Mexico City, 1860-1910
}

\author{
ANNA ROSE ALEXANDER \\ Department of History, Georgia State University, PO Box 8054, Statesboro, GA \\ 30460-8054, USA
}

\begin{abstract}
This article examines fire-safety innovations (safety matches, extinguishers and hydrants) from professional engineers and lay inventors in Mexico City from 1860-1910. With a drastic increase in the frequency and intensity of fires in the capital, engineers and entrepreneurs saw fire hazards as business opportunities. Global trends that promoted patenting new technologies spurred entrepreneurs and professionals alike to transform the capital into an epicentre of innovation aimed at making the city safer. Their inventions marked the city with visible signs of technological change and reminded residents that fire was a real threat to urban life.
\end{abstract}

On the afternoon of 24 July 1902, the Harden fire grenade company of Chicago treated Mexico City residents to a thrilling fire fighting exhibition. Representatives from the company co-ordinated a public demonstration in one of the city's main plazas to promote their handheld fire grenades to a new clientele. After building a three-by-six metre wooden wall, the Harden employees doused the wood with tar, petroleum and turpentine, scattered twigs and dried leaves along the base, and lit the wall on fire with a match. The wall started to burn rapidly and with great intensity. As the flames grew taller, nearby shop owners and residents hurried to the scene to watch the spectacle unfold. Sensing a threat to spectators and adjacent buildings, the chief of the military commission requested that the demonstration finish before anything accidentally caught fire. Despite these objections, the Harden employees calmly insisted that the fire needed to develop to its fullest extent, nearly six metres high, before they would extinguish it, thus amplifying the aura of fear and excitement in the plaza.

Ten minutes after igniting the wall, the Harden agents, finally satisfied with the size of the flames, hurled three thin-walled, blue glass balls filled with a salt water and sodium bicarbonate solution onto the blaze (Figure 1). The glass balls shattered against the wall, allowing the liquid to burst out. Sodium bicarbonate's deoxygenating effect deprived the fire 


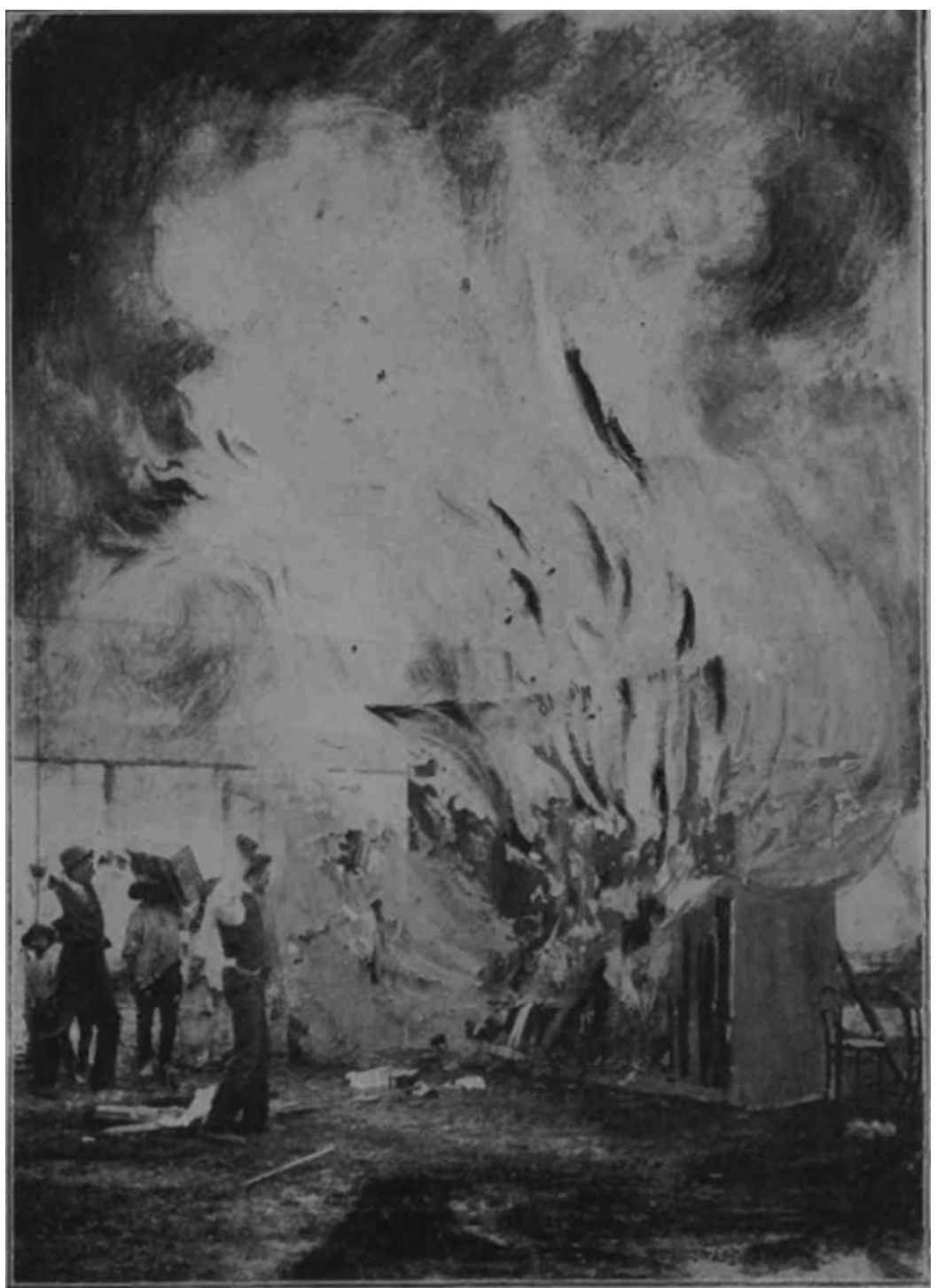

Figure 1: Harden agents throwing fire grenades onto the fire. 'Las granadas "Harden" contra incendio: un invento maravilloso', El Mundo Ilustrado (3 Aug. 1902).

of one of the elements it needed to survive, while salt water dispersed the solution effectively throughout the area. The audience, accustomed to fires being put out slowly by volunteers carrying buckets of water, roared with excitement at the sight of three small handheld fire grenades 
destroying every last glint of flame. ${ }^{1}$ Several days later, the Harden representatives repeated the performance for a high profile audience that included the secretary of public works, the chief of the fire brigade, the president of the municipal government and the inspector general of the police department. ${ }^{2}$ City officials all agreed that the grenades were ideal for fire-prone Mexico City. Human ingenuity had crushed a menacing urban problem. Because of the grenades' simple design, they boasted, even children and maids could use the glass ball to put out fires with ease. One bystander suggested that residents would no longer have to purchase costly fire insurance. Instead, the grenades could equip the city with devices to ward off destructive fires. ${ }^{3}$

While public fire grenade demonstrations had become commonplace in the United States, England and France during the last half of the nineteenth century, until 1902 Mexicans had only read about them in newspapers. In 1884, José Fernández, Mexico's minister to the United States, impressed by a similar demonstration of fire grenades in Washington DC, wrote a lengthy eyewitness account of the new product and proposed that Mexico City's municipal government purchase the grenades. Fernández included testimonies of foreign experts ranging from US fire chiefs to British fire insurance agents to show how other major metropolises had already adopted these new safety technologies, warning that Mexico was woefully underprepared to protect its citizens from fire. ${ }^{4}$ Days after the 1902 Harden demonstration, journalists explained how in France and most European nations, nearly every public building, hospital, school, estate and private home housed at least one fire grenade. Such comparisons often led to proposals for importing equipment or designing similar safety devices.

In a globalizing world, one increasingly defined by national competition, technology offered a comparative measure by which to assess national progress. ${ }^{5}$ Through newspapers, advertisements, lithographs and world's

1 'Simulacro de Incendio', El Imparcial (25 Jul. 1902), 2; 'Pruebas contra incendio', El Imparcial (4 Aug. 1902), 2.

2 'Pruebas contra incendio', El Imparcial (5 Aug. 1902), 2.

3 'Las granadas "Harden" contra incendio: un invento maravilloso', El Mundo Ilustrado (3 Aug. 1902).

${ }^{4}$ C. Rivas to Secretaría de Gobernación, 28 Jun. 1884, Archivo Histórico del Distrito Federal (AHDF): Ayuntamiento Gobierno del Distrito Federal (AGDF), Policía, Incendios, vol. 3649, exp. 84; C.M. Martin to Presidente del Ayuntamiento, 12 Aug. 1884, AHDF: AGDF, Policía, Incendios, vol. 3649, exp. 83; Jefe de Bomberos to Gobierno del Distrito, 12 Jul. 1886, AHDF: AGDF, Policía, Incendios, vol. 3649, exp. 85.

${ }^{5}$ M. Adas, Machines as the Measure of Men: Science, Technology, and Ideologies of Western Dominance (Ithaca, 1990), 3; N. Rosenberg, 'The international transfer of technology: implications for the industrialized countries', in N. Rosenberg (ed.), Inside the Black Box: Technology and Economics (Cambridge, 1982), 245-6; C. Freeman, Technology Policy and Economic Performance (London, 1987); R.R. Nelson, National Innovation Systems: A Comparative Analysis (Oxford, 1993); D. Hounshell, 'Rethinking the history of "American technology"', in S.H. Cutcliffe and R.C. Post (eds.), In Context: History and the History of Technology, Essays in Honor of Melvin Kranzberg (Bethlehem, PA, 1989), 216-29. 
fairs reports, Mexicans learned about technological innovations from around the world. ${ }^{6}$ This information gave them a way to juxtapose their nation's technologies with the machines and equipment found in other regions, and it ultimately encouraged Mexicans to create technologies specifically for domestic needs. Authors of patent requests and engineering reports often boasted of their deep pride for Mexico and how their work would improve the country's prestige on an international scale. In an 1897 report about technological innovation, engineer Gilberto Crespo Martínez spoke of Mexico's technological potential. He detailed the metric tons of coal, the length of railroad tracks and the number of telephone poles in the United States, Great Britain, Germany, France and Mexico. He concluded by explaining the ways to improve Mexico's technological shortcomings, often citing formal education for all social classes as a pathway to national improvement. ${ }^{7}$

Technological change is dependent upon the needs of a population. ${ }^{8}$ When a population demands labour-saving methods or ways to transport goods more efficiently, technology functions as a practical way of addressing those needs. It is important not to conflate the history of technology with the history of invention, because the former tends to emphasize inventions that worked and were successful. ${ }^{9}$ Nevertheless, examining both successful and failed inventions provides a glimpse into what aspects of daily life people wanted to fix in the past. In the midnineteenth century, the presence of urban fires increased around the world as the result of urbanization, industrialization and fossil fuel use. In response to living in increasingly hazardous cities, people were challenged to conceive of new and innovative ways to protect themselves and their investments from misfortune. An emerging culture of fear toward fire hazards made a market demand for protection. Engineers and inventors, knowing that there was a potential clientele of people concerned about

${ }^{6}$ Even though at large international expositions (such as the World's Fairs) Mexican exhibits did not normally display inventions and machines, Mexicans who attended saw the innovations developed in other parts of the world. M. Tenorio Trillo, Mexico at the World's Fairs: Crafting a Modern Nation (Berkeley, 1996), 134.

7 G. Crespo Martínez, Las patentes de invención (Mexico City, 1897), 9-11, 85.

8 R. Friedel, A Culture of Improvement: Technology and the Western Millennium (Cambridge, MA, 2007); E. Layton, 'Mirror-image twins: the communities of science and technology in nineteenth-century America', Technology and Culture, 12 (1971), 562-89; M.R. Smith and L. Marx, Does Technology Drive History? The Dilemma of Technological Determinism (Cambridge, MA, 1994). One of the most neglected facets of Latin America's urban modernizing experience has been analysis of patterns of technological change. Some notable exceptions in Latin America include M. Perló Cohen, El paradigma porfiriano: historia del desagüe del valle de México (Mexico City, 1999), 287; A. Rosenthal, 'Dangerous streets: trolleys, labor conflict, and the reorganization of public space in Montevideo, Uruguay', in R. Pineo and J.A. Baer (eds.), Cities of Hope: People, Protests, and Progress in Urbanizing Latin America, 1870-1930 (Boulder, CO, 1998), 30-52.

9 D. Edgerton, 'Innovation, technology, or history: what is the historiography of technology about?', Technology and Culture, 51 (2010), 686. 
their safety, harnessed these fears, designing ways to reduce fire risks. Inventors especially sought to profit from these ventures. Despite the fact that all urban neighbourhoods, both rich and poor, had to confront physical destruction by fire, not all members of society could afford to purchase the newly invented items to fight fires. Therefore, invention did not necessarily mean widespread adoption and use.

By analysing technological change, this project captures how trained engineers and amateur inventors used their unique knowledge and experiences to address both environmental constraints and social needs. Urban fires meant different things to government engineers, foreign businessmen and domestic entrepreneurs. Some of these groups interpreted the citizenry's fears of fire as business opportunities, while others saw them as avenues to gain prestige and government commissions. Comparing the works of trained engineers with those of lay inventors shows that this process was much more than a top-down attempt to make the city safer and appear modern. Engineers argued that the sole purpose of their craft was to apply science to daily problems and to find the most cost-effective solutions to harness and control the energies and materials of the natural world. ${ }^{10}$ Fire represented one of those daily problems. Finding ways to divert streams and supply water with enough pressure to shoot out of hydrants required that engineers creatively manipulate and utilize their natural surroundings. Yet assessing only the projects initiated by degree-holding engineers, whether in Mexico or abroad, ignores the important contributions that other citizens made to combat fires. Independent inventors listened to residents' growing dissatisfaction and created devices and contraptions that spoke directly to those who had anxieties and fears about fires. Inventors wanted to profit from their work, so they built items for a clientele that was supremely worried about fires, craftily interpreting and engaging the social context to launch their business enterprises. While historiographical interpretations of this time period are full of examples of technology transfer and Mexicans importing and adopting technology, medicine and equipment from the United States and Europe, the important home-grown attempts at technological improvements remain understudied. ${ }^{11}$ In both cases, these fire technologies provide insight into the making of an urban metropolis in the late nineteenth century.

10 J.R. de Ibarrola, Apuntes sobre el desarrollo de la ingeniería en México y la educación del ingeniero (Mexico City, 1911), 6.

11 E. Aréchiga Córdoba, 'La ciudad y Tepito: a la zaga de la higiene pública', in E. Aréchiga Córdoba (ed.), Tepito: del antiguo barrio de indios al arrabal (Mexico City, 2003), 171207; T. Benjamin and M. Ocasio-Meléndez, 'Organizing the memory of modern Mexico: porfirian historiography in perspective, 1880s-1980s', Hispanic American Historical Review, 64 (1984), 363; E. Beatty, 'Approaches to technology transfer in history and the case of nineteenth-century Mexico', Comparative Technology Transfer and Society, 1 (2003), 167-200. 


\section{Igniting fear: the rise of fire hazards in Mexico City}

Salvador Novo, the capital's most famous chronicler of urban life, described Mexico City in the late nineteenth century as a place devoid of an extensive public culture. ${ }^{12}$ Despite his strong criticism, recent scholarly work suggests that the city was vibrant and energetic, with bustling commercial sectors full of department stores and an active nightlife. ${ }^{13}$ Butchers' shops, charcoal factories, cobblers' workshops and French dress boutiques crowded the avenues and plazas. Over the course of several decades, pavement, cobblestone and boardwalk-style wood planks replaced dirt roads, allowing trolleys to traverse the cemented streets and transport residents to every corner of the city. Rural dwellers and foreigners alike flocked to the capital seeking employment and ways to participate in these exciting urban developments, more than doubling the capital's population between 1860 and $1910 .{ }^{14}$ The city went from a quiet capital to thriving urban centre. For some, the transformation represented a renaissance. For others, it led to horrid living and working conditions. ${ }^{15}$ No matter who benefited from these transformations, the city changed for everyone, a trend that was occurring in cities throughout the world.

The increase in urban fires in Mexico City and across the world came as the result of rapid industrialization and urban growth coupled with an increased dependence on fossil fuels. These factors came together to form what environmental historian Stephen Pyne calls a nineteenth-century industrial fire regime. Simply put, fire regimes represent contextual circumstances that define the patterns in which fires occur. Many of these new urban developments contributed to an increase in fire hazards. ${ }^{16}$ Environmental factors ranging from weather conditions to natural resources, in combination with political and economic determinants such as industrial production and population growth, made cities prone to explosions and hotter, longer-burning fires. ${ }^{17}$ Mexican buildings, made of adobe or tepetite, a composite of stone and pumice held together with a

12 S. Novo, Seis siglos de la ciudad de México (Mexico City, 1974).

13 S. Bunker, Creating Mexican Consumer Culture in the Age of Porfirio Díaz (Albuquerque, 2013); F. Gamboa, Santa, trans. J.C. Chasteen (Chapel Hill, 2010), 3-5.

14 Between 1860 and 1910, the population exploded from 190,000 to 417,000 inhabitants. E. Berra, 'La expansión de la Ciudad de México y los conflictos urbanos, 1900-1930', unpublished Colegio de México Ph.D. thesis, 1983, 88; J. Galindo y Villa, Reseña históricadescriptiva de la Ciudad de México que escribe el Regidor del Ayuntamiento, por encargo del Señor Presidente de la misma corporación D. Guillermo Landa y Escandón, y expresamente para los delegados a la segunda conferencia internacional americana (Mexico City, 1901), 7-8.

15 A. Rama, The Lettered City, trans. J.C. Chasteen (Durham, NC, 1996), 22.

16 Several fire historians have noted how the introduction of mass industry and new chemicals made fire a part of daily life; see G. Vaughan Blackstone, A History of the British Fire Service (London, 1957), 1; S.J. Pyne, Fire: A Brief History (Seattle, 2001), 11215; R. Pearson, Insuring the Industrial Revolution: Fire Insurance in Great Britain 1700-1850 (Aldershot, 2004).

17 Pyne, Fire: A Brief History, 106-18; S.J. Pyne, World Fire: The Culture of Fire on Earth (Seattle, 1997), 23-5. 
clay-like substance, had traditionally been quite fireproof. ${ }^{18}$ By the midnineteenth century, architects started to embrace Parisian-style wooden mansard roofs and wooden-constructed sidewalks to adorn the capital city, and residents used combustible fuels on a daily basis. Consequently, Mexico City became more flammable. ${ }^{19}$

Mexico City never had a conflagration on the scale of the Great Chicago Fire of 1871, the Paris Opera Fire of 1887, the Great Fire in Shanghai in 1894 or the San Francisco Earthquake Fire of 1906. Nonetheless, reporting on the horrors of big and small fires around the world became a standard practice in most major Mexican newspapers, and the frightening reports of these disasters haunted the capital's residents. ${ }^{20}$ For several days after the 1906 San Francisco earthquake and fire, the front page of El Imparcial was covered in articles that detailed the disaster and described the relief measures implemented in a city consumed by flames and buried in rubble. ${ }^{21}$ Stories of flames devouring more than 1,000 homes in Shanghai in 1894, or of the sounds of screaming patients locked in their cells during a fire at a mental asylum in Montreal in 1890, entered Mexican homes and made citizens question their own fire safety. ${ }^{22}$ Some officials kept meticulous records of these worldwide urban hazards to learn from the mistakes and oversights of others, and implemented the latest fire fighting strategies whenever possible. Other officials evaded purchasing expensive equipment by arguing that Mexico City's unique use of adobe for buildings and the heavy summer rains made the capital less flammable than major cities in the United States and Europe. ${ }^{23}$

Capital residents noticed a considerable increase in the frequency and intensity of fires, and wrote petitions explaining how the fire-safety precautions being taken had become futile. ${ }^{24}$ Mexico City's newspapers

18 Casa de Comercio de los Estados Unidos de las Bombas de incendio, 13 Feb. 1864, AHDF: AGDF, Bombas y Locomóviles, vol. 438, exp. 7; Prefectura Política del Departamento del Valle de México, 13 Feb. 1865, AHDF: AGDF, Bombas y Locomóviles, vol. 438, exp. 7; 'The great fire in the city of Mexico', Milwakee Sentinel and Gazette (9 May 1850).

19 European and North American cities experienced a decrease in fires due to the almost universal adoption of brick construction, L.E. Frost and E.L. Jones, 'The fire gap and the greater durability of nineteenth-century cities', Planning Perspectives, 4 (1989), 340-1; S.E. Wermiel, The Fireproof Building: Technology and Public Safety in the Nineteenth-Century American City (Baltimore, 2000).

20 'El incendio en Chicago, golpe de vista' (23 Jul. 1893), 'Incendio de la exposición de Chicago' and 'Incendio en Chicago', Monitor Republicano (14 May 1885), 4.

21 'Terrible catástrofe: San Francisco convertido en ruinas', El Imparcial (19 Apr. 1906); 'Las ruinas de San Francisco: relato de un testigo presencial', El Imparcial (20 Apr. 1906); 'El Incendio Cesa: comienzan á llegar auxilios', El Imparcial (21 Apr. 1906); 'La reconstrucción de San Francisco: límites exactos de la zona destruido', El Imparcial (22 Apr. 1906); 'San Francisco renace: ya se levantan nuevos muros', El Imparcial (24 Apr. 1906).

22 'Incendio de una casa de locos', El Siglo Diez y Nueve (6 Jun. 1890), 2; 'Detalles de un incendio', Voz de México (10 Jun. 1890), 1.

23 A.S. Greenberg, 'Fighting fires (or not) in porfirian Mexico', in G. Bankoff, U. Lübken and J. Sand (eds.), Flammable Cities: Urban Conflagration and the Making of the Modern World (Madison, 2012), 128.

24 'Boletín del “Monitor"', El Monitor Republicano (28 Sep. 1882), 1. 
reported daily on large and small conflagrations throughout the city, thus corroborating residents' concerns about fires. Published stories of spontaneously combusting match boxes, pyrotechnics shooting from burning fireworks factories, or household varnishes catching fire and leaving bodies permanently scarred, perpetuated a collective fear of urban fire. ${ }^{25}$ The available records about the number of fires remain spotty. Data from hospital registries or public health institutions give some indication of the number of burned victims who sought out medical attention, yet disregard anyone who tended to their burns at home. ${ }^{26}$ In light of growing fire risks, public health officials folded fire prevention into the city's sanitation code, and municipal officials implemented fire codes and developed a professional fire fighting brigade modelled after the Parisian fire department. ${ }^{27}$ Much like British police fire brigades and the French sapeurs-pompiers, Mexican firemen operated under the control of the police department, headed by the police chief. ${ }^{28}$ In western Europe and the United States, a similar bureaucratic shift had also occurred in the mid-nineteenth century, which made local governments administer public services that had previously been a neighbourhood or community-level responsibility. ${ }^{29}$

By designing methods and machines to combat the increasing prevalence of fire hazards, engineers and inventors tried to become part of a growing trend in Mexico that privileged scientists as voices of authority in society. The nineteenth century marked an era when scientific occupations became more common. In an effort to increase industrial output, Germany, France and England created technical schools and paved the way for

25 'Combustión espontánea y parcial', El Universal (22 Dec. 1853), 4; 'Incendio en una cohetería', El País (13 Oct. 1903), 2; 'Sufrió quemaduras al incendiarse el alcohol', El Diario (26 Aug. 1911), 8.

26 The records for 1860 and 1864 show that of the 406 patients admitted to the Hospital Juárez for burns, 72 of them died. F. García Sepúlveda, 'Estadística general del Hospital Juárez, 1888-1895', unpublished Escuela de Medicina thesis, 1896; for some perspective, 3,125 people died from burns in the United Kingdom in 1858; see 'Deaths from the inflammability of clothing', The Lancet (8 Sep. 1860), 245.

27 'Iniciativa: para la reglamentación en el Distrito Federal de los establecimientos peligrosos, insalubres, e incómodos', Boletín del Consejo Superior de Salubridad, 3, 1 and 2 (1882), 1-3; The first real attempt to recruit men for the fire brigade occurred in 1856, but it took several decades to make a fire department a reality; see J.J. Baz, Gobernador del Distrito, Decreto expedido por la secretaría de estado y del despacho de Gobernación sobre la organización de un cuerpo de policía denominado de zapadores bomberos, se adjunta el Reglamento para dicho cuerpo de policía, 1856, Archivo General de la Nación (AGN): Gobierno del Distrito 127, caja 451, exp. 16; Reglamento para el Batallón de Zapadores-Bomberos, 18 Jun. 1850, AHDF: AGDF, Policía: Incendios, vol. 3649, exp. 51; Don Juan Turín sobre que se forme un cuerpo de Zapadores Bomberos y se le nombre su Instructor, 25 Apr. 1854, AHDF: AGDF, Policía: Incendios, vol. 3649, exp. 57; Comisaría Central de Policía, 23 Mar. 1866, AHDF: AGDF, Policía: Incendios, vol. 3649, exp. 59, fols. 27-9.

28 S. Ewen, Fighting Fires: Creating the British Fire Service, 1800-1978 (New York, 2009), 3-4; M. Tebeau, Eating Smoke: Fire in Urban America, 1800-1950 (Baltimore, 2003), 251.

29 E. Higgs, The Information State in England: The Central Collection of Information on Citizens since 1500 (Basingstoke and New York, 2004), 64-6; J.A. Tarr, The Search for the Ultimate Sink: Urban Pollution in Historical Perspective (Akron, 1996); M. Melosi, The Sanitary City: Urban Infrastructure in America from Colonial Times to the Present (Baltimore, 2000). 
scientific professionalization. The general belief that scientific education was the key to advancement gave engineers a prominent social profile. ${ }^{30}$ In Mexico, the acclaimed group of men known as the científicos, so named because of their belief that the methods of science could be applied to political matters, acted as unofficial advisors to President Porfirio Díaz (1876-80 and 1884-1911). By following a form of Comtean Positivism, they privileged science as the highest form of knowledge, and thought that science could guide society toward a modern existence. The cientificos' main goal was to apply scientific logic to solve the problems of everyday life. ${ }^{31}$ Public services such as water management, economic development, reforestation and fire prevention all came under the care of men who applied observational and experimental science to the art of constructing machines, engines and structures. ${ }^{32}$ Adapting to a political and social environment that honoured science, engineers and inventors created new devices or processes that showcased one's imagination and ingenuity.

\section{Controlling nature: protection and infrastructure}

The development of the National School of Engineering in 1868 initiated an era of professional specialization and represented a major cultural turn, one that made graduates of this academy valued members of society capable of offering calculated responses to urban problems. ${ }^{33}$ Students accepted into the National Engineering School received free training made possible through public funds. Professors and administrators claimed that offering publicly funded educational programmes compelled graduates to use their training in the public sector, rather than for the purpose of accruing large salaries in private corporations, as their counterparts in the United States. ${ }^{34}$ Francisco de Garay, an engineer of the time, explained that engineering was not a lucrative profession, but a noble one that had intrinsic value in society. ${ }^{35}$ Engineers thus carried an obligation to apply their understandings of science and technology to improve life and to

${ }^{30}$ P.R. Josephson, Industrialized Nature: Brute Force Technology and the Transformation of the Natural World (Washington, 2002), 3.

31 F.X. Guerra, México: del antiguo régimen a la revolución (Mexico City, 1988), 380; C. Hale, Transformation of Liberalism in Late Nineteenth-Century Mexico (Princeton, 1989), 31; L. Sánchez Agesta, El pensamiento político del despotismo ilustrado (Madrid, 1953), 16; P.A. Palou, 'Intelectuales y poder en México', América Latina Hoy, 47 (2007), 80-1.

32 R.H. Kargon and S.G. Knowles, 'Knowledge for use: science, higher learning, and America's new industrial heartland, 1880-1915', Annals of Science, 59 (2002), 14; E. Wakild, Revolutionary Parks: Conservation, Social Justice, and Mexico's National Parks, 1910-1940, Latin American Landscapes (Tucson, 2011).

33 J.L. Tamayo, Breve reseña sobre la escuela nacional de ingeniera (Mexico City, 1958), 46; L. Nash, 'The changing experience of nature: historical encounters with a northwest river', Journal of American History, 86 (2000), 1611-14.

34 Ibarrola, Apuntes sobre el desarrollo de la ingeniería, 23.

35 Francisco de Garay, Discurso ponunciado por el ingeniero Francisco de Garay en la Asociación de Ingenieros Civiles y Arquitectos, al tomar posesión de la presidencia de la misma (Mexico City, 1877), 8. 
put Mexico on par with other modern countries in terms of urban safety, infrastructure and innovation. This university-trained, middle-class group of engineers successfully crafted a professional identity based on social contribution and educational pedigree. ${ }^{36}$

Engineers held strong convictions that through education and training they could control natural forces for human benefit, in effect combating the ills of the natural world through technology. ${ }^{37}$ Harnessing water energy marked one of the most important engineering feats in Mexico City. Engineers found ways to re-route streams, funnel liquid through underground pipes and pump water out of previously untapped aquifers to provide residents with the water they needed to live in the city. Drinking, washing clothes, powering industries and putting out fires all required extensive amounts of water, and natural water supplies had failed Mexico City's residents as they were unable to keep up with the demands of the growing population. The majority of the water supply in Mexico City came from spring water from ranches in the northern outskirts of the city. Even though the springs offered clean and accessible water to residents, they had little natural water pressure behind them and could not be propelled long distances. ${ }^{38}$ The increased use of piped water in homes and businesses meant that water pressure decreased dramatically. In order to use hydrants to extinguish fires, everyone living in surrounding streets had to shut off their water valves in order to increase water pressure, which required extensive co-ordination and co-operation. By 1872, the chief of police pleaded with the city council to commission a map of all the valves in homes and businesses so that policemen and guardsmen could more quickly manipulate water pressure during fire emergencies. ${ }^{39}$ Despite his request, the city council responded that it would be too difficult to create an accurate map of all the valves, faucets and wells located in homes and businesses throughout the city.

To begin the long process of improving water pressure to fire hydrants, engineers spent seven years creating an extensive map of all the hydrants and corresponding pipes in the city. In addition to explaining the location of each hydrant, the engineers described the diameter of the pipes that supplied each hydrant with water. By 1877, more than 50 fire hydrants sat

36 A. Abbott, The System of Professions: An Essay on the Division of Expert Labor (Chicago, 1988); M.A. Calvert, The Mechanical Engineer in America, 1830-1910: Professional Cultures in Conflict (Baltimore, 1967), 191; J. Fisher and N. Priego, 'Ignorance and "habitus": blinkered and enlightened approaches towards the history of science in Latin America', Bulletin of Latin American Research, 25 (2006), 528-40; B. Sinclair, A Centennial History of the American Society of Mechanical Engineers, 1880-1980 (Toronto, 1980), 25-6 and 61; A. Slaton, Reinforced Concrete and the Modernization of American Building, 1900-1930 (Baltimore, 2001), 21-5.

37 A. Díaz Rugama, 'Distribución y legislación de aguas en las ciudades', in Concurso Científico. Asociación de Ingenieros y Arquitectos. Discurso pronunciado en la sesión del 22 de julio de 1895 (Mexico City, 1895); Ibarrola, Apuntes sobre el desarrollo de la ingeniería, 6.

38 Galindo y Villa, Reseña histórica-descriptiva de la Ciudad de México, 166-7.

39 Inspector General de Policía to Gobierno del Distrito Federal, 16 May 1872, AHDF: AGDF, Aguas en General, vol. 36, exp. 202, fols. 1-2. 
on street corners throughout the city. Even the lower-class neighbourhood of Tepito, located north-east of the cathedral and main plaza, had hydrants, albeit only two to protect that entire area. For the most part, hydrants sat in front of government buildings, plazas, monuments, gardens and some churches. In their reports about the locations and quality of fire hydrants, engineers noted that many of the hydrants near the periphery of the city did not work well. The hydrants outside of the city centre functioned so poorly that the engineers thought it would be better to fill buckets of water at one of the nearby household wells than to attempt to use some of the hydrants for putting out fires. ${ }^{40}$ Using this 1877 report and his own assessments of the capital's water infrastructure, engineer and businessman Carlos Medina discovered that of the 333 piped streets, only 185 of them had been equipped with the shut-off valves essential to fight fires. ${ }^{41} \mathrm{He}$ estimated that the city lacked more than 1,400 valves needed to shut off water and put out fires quickly.

In their attempts to improve the city's water network, engineers encountered a series of issues that stemmed from previous infrastructural plans. Most importantly, they had to confront the earlier, non-coordinated and non-regulated engineering efforts that continued to lie beneath the city. Ill-fitted lead pipes of various diameters meandered below the capital. Inspectors and engineers, appalled at the poor condition of the deteriorating infrastructure, expressed concerns about the leaky pipelines. ${ }^{42}$ Leaks not only meant water loss, but also that sewage and other materials could seep into the pipes and threaten public hygiene. The small trickles of water could easily break down the fragile lakebed soil that undergirded the city, which could be devastating to a city prone to earthquakes. ${ }^{43}$ Each leak also decreased, if only slightly, the amount of water pressure in the pipes. Engineers tried to reconfigure and improve the water system, but before doing so they needed to repair or remove layers of old, intertwined pipes, establish distinct piping networks for potable water and non-potable water (the later being used for industry and fire extinction $)^{44}$ and build a system that had sufficient water and pressure to put out fires.

40 Se ordena al Ayuntamiento de la capital, remita a este Gobierno un plano de todas las Cañerías de agua que cruzan las calles de la capital, para tomarla en caso de incendio, 1870-77, AHDF: AGDF, Aguas, vol. 1311, exp. 342.

41 C.A. de Medina, Exposición que hace el Ingeniero Carlos A. de Medina a todos los habitantes de la ciudad de México sobre las grandes ventajas que trae consigo para la capital (Mexico City, 1884), 18.

42 L. Salazar, 'On the distribution of water in the city of Mexico', International Engineering Congress, 30 (1893), 344.

43 Soil liquefaction caused extensive property damage and loss of life during the 1985 earthquake in Mexico City; see E. Poniatowska, Nothing, Nobody: The Voices of the Mexico City Earthquake, trans. Aurora Camacho de Schmidt and Arthur Schmidt (Philadelphia, 1995).

${ }^{44}$ Salazar, 'On the distribution of water in the city of Mexico', 348. 
City engineers advised the municipal council to spend roughly 40 million pesos to develop hydraulic infrastructure in the capital. ${ }^{45}$ During this expensive and time-consuming construction period, workers laid more than 2,500 tons of imported British pipes beneath the city. Engineers also sought to use gravity to help create the necessary water pressure to operate most faucets throughout the city by storing water in elevated cisterns in Chapultepec Park, the highest point in the city. The park housed three British Worthington brand water pumps that sucked water up quickly (12 cubic metres per minute) from the massive holding tanks and efficiently pushed it into the pipes that gridded the city. ${ }^{46}$ While engineers had designed many of the pipes for drinking water or drainage, putting out fires remained at the forefront of hydraulic engineers' minds. In 1897 alone, nine high-pressure fire hydrants were installed in the capital.

Even though engineers overhauled the capital's entire water network, fire protection technologies tended to benefit some sectors of society more than others. ${ }^{47}$ Engineers and the city council members who allocated funds had competing visions about where public works would go and who would reap their benefits. ${ }^{48}$ Understandably, the hydrants sat in places with pre-existing pipelines, especially near the centre of the city. As the city's size more than quadrupled between 1858 and 1908, eventually becoming known as the 'city of suburbs', the process of getting public works to extend to every corner of the city proved difficult. ${ }^{49}$ The fire chief and the city engineer expressed concerns that the majority of hydrants had been installed in strategic locations, often in the centre of the city and in front of upper-class theatres or major business districts, thus assisting only the wealthiest sectors of society in emergency situations. The chief, citing his experience with urban fires, explained that the current fire hydrant infrastructure needed to be expanded drastically because fire hazards plagued all neighbourhoods in the city, regardless of the socio-economic status of their residents. ${ }^{50}$ Near the turn of the century, the city council paid for the installation of dozens of hydrants. More often than not, those

${ }^{45} \mathrm{M}$. Vitz, 'Revolutionary environments: the politics of nature and space in the valley of Mexico, 1890s-1940s', unpublished New York University Ph.D. thesis, 2010, 38.

46 Salazar, 'On the distribution of water in the City of Mexico', 344-7.

47 For additional information about water infrastructure in cities, see Melosi, The Sanitary City; M. Rawson, 'The nature of water reform and the antebellum crusade for municipal water in Boston', Environmental History, 9 (2004), 411-35.

${ }^{48}$ M. Reuss, 'Seeing like an engineer: water projects and the mediation of the incommensurable', Technology and Culture, 49 (2008), 532.

${ }^{49}$ M. Dolores Morales, 'La expansión de la ciudad de México en el siglo XIX: el caso de los fraccionamientos', in A. Moreno Toscano and C. Aguirre (eds.), Ciudad de México: Ensayo de Construcción de una historia (Mexico City, 1978), 190.

50 Comandante del Cuerpo de Bomberos to Presidente del Ayuntamiento, 8 Mar. 1897, AHDF: AGDF, Aguas en General, vol. 40, exp. 467, fols. 5-8. 
hydrants continued to sit in front of places of national patrimony, next to central theatres and alongside upper-class neighbourhoods. ${ }^{51}$

As in other growing cities in Latin America and elsewhere, new infrastructure brought new regulations. ${ }^{52}$ City engineers assumed the task of inspecting hydrants and valves every month to ensure that they functioned properly. ${ }^{53}$ In 1903, engineers recognized the importance of the monthly hydrant inspection after firemen tried to put out a fire in a corner store, but could not use the hydrants because the pipes and valves had become clogged with dirt. Instead, firemen had to carry water, bucketby-bucket, from a neighbour's artesian well, prolonging the disaster. ${ }^{54}$ Soon thereafter, following a series of repairs by city engineers, the revered hydrants became untouchable to anyone except trained professionals. Newly minted legislation, intended to protect fire-safety equipment, stipulated that anyone caught touching or tampering with a hydrant would be fined 20 pesos. ${ }^{55}$ Residents who had little or no access to water taps and fountains had grown to depend on the water in fire hydrants for household purposes, including bathing or washing clothes. ${ }^{56}$ Every day for several months, a gardener who tended the plants in the Plazuela de Carlos IV employed that plaza's fire hydrant to water the garden. When a fire erupted in the Plaza de Toros de Bucareli, firemen discovered that the gardener had somehow damaged the valve, making it useless in extinguishing the devastating Bucareli fire. ${ }^{57}$

The need for water made engineers essential in the fight against fires in Mexico City. While drafting regulations and inspecting factories encompassed a major part of their jobs, it was through the technology and machines they created that they reminded people about the positive work they had done for the city. In an era of foreign investment and foreign expertise, local engineers became well regarded for their ability to understand specifically Mexican issues based on geography and

51 J. Bribiesca, Memoria documentada de los trabajos municipales de 1900, vol. I, tomo I (Mexico City, 1901), 349 and 392; Comisiones de Hacienda y Aguas, 16 Jan. 1902, AHDF: AGDF, Aguas: Arquerías y Acueductos, Cañerías, vol. 23, exp. 454.

52 S.J. Martland, 'Taming fire in Valparaíso, Chile, 1840s-1870s', in Bankoff, Lübken and Sand (eds.), Flammable Cities, 72-4; K. McCleary, 'Inflaming the fears of theatergoers: how fires shaped the public sphere in Buenos Aires, Argentina, 1880-1910', in ibid., 257-61.

53 Bribiesca, Memoria documentada de los trabajos municipales de 1900, 343.

${ }^{54}$ Inspector General to Secretario del Gobierno del Distrito, 15 Apr. 1903, AHDF: AGDF, Gobierno del Distrito, Aguas, vol. 1327, exp. 1456.

55 El Comisionario de la 6a demarcación remite el acta levantada con motivo que Andrés López y otros sacaban agua de la toma para incendios en Chapultepec y San Antonio, 1904-07, AHDF: AGDF, Gobierno del Distrito, Aguas, vol. 1328, exp. 1487; La dirección general de obras públicas pide se prevenga a la policía cuide del público no haga uso de la válvulas de incendio, 1904-07, AHDF: AGDF, Gobierno del Distrito, Aguas, vol. 1328, exp. 1517.

56 Vitz, 'Revolutionary environments', 49.

57 Jefe de Bomberos to Administrador de Paseos, 28 Apr. 1896, AHDF: AGDF, Aguas en General, vol. 40, exp. 475, fols. 1-2. 
environment. ${ }^{58}$ Hydrants, pipes, faucets and pumps visibly marked the city with the influence of the engineers' craft, but those technologies only helped certain neighbourhoods. Lay inventors took protection one step further and brought smaller fire-safety devices into the homes of Mexico City residents.

\section{Inventiveness: patrimony and profits}

Engineer Bruno Ripoll, one of the characters in Federico Gamboa's 1903 novel Santa, bridges the gap between formal engineer and informal inventor. In awe of his ability to read massive books full of technical jargon, tenants at the Gupuzcoana boarding house, where he lived, respected Ripoll for his academic achievements and his devotion to his craft. His fellow boarders envisioned the great social benefits that could come from his scientific musings and mechanical designs, and gave him space and quiet to conduct his work. The owner of the boarding house, Doña Nicasia, even awarded Ripoll months upon months of free room and board because she trusted that his work would eventually earn him mountains of pesos with which to pay her back. ${ }^{59}$ These boarders saw in Ripoll what Mexico City residents saw in other engineer-inventors of the time: an educated, erudite man willing to use his knowledge to improve public life in the capital city. In many ways, he typified the late nineteenth-century heroic inventor motif. ${ }^{60}$ The boarders adored him, not because he had invented anything that gained widespread acceptance, but because of the possibility that he might do so. Much like other inventors of his time though, his promises fell short, and he could not translate his knowledge into a practical result. ${ }^{61}$ His lofty plans to build a submarine never materialized and the boarders eventually lost interest in Ripoll and the owner kicked him out of her boarding house for not paying his rent.

Indeed, other inventors in Mexico had similar stories as the engineer Ripoll, but while engineers openly publicized their academic credentials

58 M. Bazant, 'La enseñanza y la práctica de la ingeniería durante el Porfiriato', in J. Zoraida Vázquez (ed.), La educación en la historia de México (Mexico City, 1992), 1679; M. de la Paz Ramos Lara and R. Rodríguez Benítez, Formación de ingenieros en el México del siglo XIX, Ciencia y Tecnología en la Historia de México (Mexico City, 2007); J. Palacios, 'Memoria sobre incendio del pozo de petróleo de 'Dos Bocas', Boletín de la sociedad Mexicana de Geografía y Estadística, quinta época, 3 (1908), 23.

59 Gamboa, Santa, 116-17.

${ }^{60}$ During this age of heroic inventors, popular literature and biographies praised amateur inventors and highlighted the exceptional rags to riches stories, see C. MacLeod, 'The invention of heroes', Nature, 460 (2009), 572-3; C. MacLeod, 'Concepts of invention and the patent controversy in Victorian Britain', in R. Fox (ed.), Technological Change: Methods and Themes in the History of Technology (Amsterdam, 1996), 137-8; T.P. Hughes, Elmer Sperry. Inventor and Engineer (Baltimore, 1971); G. French, The Life and Times of Samuel Crompton, Inventor of the Spinning Machine Called the Mule (London and Manchester, 1859).

61 W.H. Beezley, 'Mexican sartre on the zócalo: Nicolás Zúñiga y Miranda', in J. Ewell and W.H. Beezley (eds.), The Human Tradition in Latin America: The Nineteenth Century (Wilmington, 1989), 204-14. 
to justify their work, the majority of lay inventors asserted their authority in other ways. To give authority and legitimacy to their inventions, they highlighted their experiences as match vendors, factory owners, construction workers, theatre employees and housewives. ${ }^{62}$ This group of lay inventors included, among others, well-off businessmen from Mexico and abroad who did not solely rely on the profits from their machines or devices to live. Usually, it was through their daily occupations that they stumbled on an area in need of improvement or streamlining. One industrialist, native to Mexico City, thought that his experiences owning several factories in the capital made him different from most inventors, because he was keenly aware of the types of fires that tended to erupt in factories and stores. Accordingly, he invented a handheld extinguisher aptly named the 'Flame Killer' ${ }^{63} \mathrm{M}$. Cisneros, a trained contractor from the capital, witnessed great flaws in the construction of roofs, and he used his occupational experience to develop a new process to build non-flammable roofing materials. ${ }^{64}$ Carmen Chávez, a wife, mother and homemaker who was supremely concerned about the safety of her home and her children, mixed together an assortment of household substances in order to produce a fireproof paste to spread onto rooftops and walls. ${ }^{65}$ The art of invention took on personal dimensions. Not only did an invention have to work well and offer a technological solution to life's ills, but also the inventor had to sell it to the patent granting office and to customers.

From 1880 to 1910, the number of patents registered by Mexican inventors skyrocketed from 24 to 1,308. Despite this dramatic increase, only one in four of the total patents during this period came from a nativeborn Mexican. ${ }^{66}$ That ratio was higher for fire-safety patents. Between 1858 and 1914, roughly half of the 50 fire-safety patents that arrived at Mexico's patenting office came from Mexican-born inventors. In their patent applications, domestic and foreign inventors spoke patriotically of technology paving the way to progress and modernity. In effect, inventors reiterated the rhetoric of Comtean Positivism adopted by

${ }^{62}$ Díaz y Sala, una composición para extinguir fuego de cualquier naturaleza, 18 Apr. 1905, AGN: Patentes y Marcas, leg. 308, exp. 12, fol. 1; Rubén Martí, un extinguidor para incendios, 21 Jan. 1908, AGN: Patentes y Marcas, leg. 308, exp. 19, fols. 1-3; Reinaldo Rodríguez Arce and Everardo Rodríguez Arce, un procedimiento para extinguir incendios en pozos de petróleo o gas, 29 Jul. 1908, AGN: Patentes y Marcas, leg. 308, exp. 20, fols. $1-4$.

${ }^{63}$ Díaz y Sala, una composición de materias para extinguir las flamas en los incendios denominada 'mata flama', 8 July 1910, AGN: Patentes y Marcas, leg. 308, exp. 27, fol. 1.

${ }^{64}$ M. Cisneros, un procedimiento para la fabricación de un techo impermeable, 15 Apr. 1905, AGN: Patentes y Marcas, leg. 285, exp. 47.

65 C. Chávez, Fabricación de una pasta impermeable denominada invulnerable, AGN: Patentes y Marcas, leg. 285, exp. 58.

66 E. Beatty, 'Patents and technological change in late industrialization: nineteenth-century Mexico in comparative context', History of Technology, 24 (2002), 138; E. Beatty and J.P. Sáiz, 'Industrial property institutions, patenting, and technology investment in Spain and Mexico, c. 1820-1914', Economic History Working Paper Series, Universidad Autónoma de Madrid (2007), 25. 
politicians, scientists, educators and political advisors who believed that the application of science in public policy led to social progress. ${ }^{67}$ The historical context of a nation trying to achieve modernity by improving its industrial output and applying science to social problems shaped how technology developed in the capital. ${ }^{68}$

Fire-control or prevention devices had the potential to benefit everyone in Mexico City, and this prompted local and national officials to encourage residents to invent machines, chemicals or apparatuses to make the city safer. In select cases, such as the 1884 official request for the development of safety matches, political authorities looked to the public to solve problems through ingenuity and innovation. ${ }^{69}$ Government officials, businessmen and investors identified match production in the capital as an area in dire need of redesign. In 1884, Porfirio Parra, a medical doctor, supporter of científico intellectuals and advocate of Positivist thought, asked the capital's citizens to submit designs for safety matches. ${ }^{70}$ The available matches, known for being highly flammable, spontaneously combustible and dangerous to the health of workers in match factories, offer a superb example of something that needed to be improved in order to conform to the demands of urban life. Knowing the government's aspirations to create a thriving manufacturing industry in the capital, one inventor remarked how safer factory settings, as a result of his safety matches, would undoubtedly lead to more profitable national industries. ${ }^{71}$ Other inventors commented on the steep prices that safety devices carried, and in turn tried to use inexpensive materials so that everyone in the capital could afford to buy matches. They claimed that by making safety more affordable to members of all social classes, everyone in the country benefited. ${ }^{72}$ Inventors invoked national symbols, sometimes going so far as to name a device after politicians, such as the Extinguidor Universal Porfirio Díaz, in order to get a patent request approved. ${ }^{73}$

Fire-safety inventions offer insight into how people linked technological innovation with ideas about hygiene and progress. Mexico City physicians and sanitation inspectors asserted that public health and well-being offered the clearest example of progress in cities, especially during the

67 A. Comte, The Positive Philosophy, trans. Harriet Martineau (New York, 1856), $26-7$.

68 Smith and Marx, Does Technology Drive History?, 38; D. MacKenzie's study of the nuclear missiles shows that institutions and politics, stemming from a specific social context, determined what technological improvements needed to be made, Inventing Accuracy. A Historical Sociology of Nuclear Missile Guidance (Cambridge, 1990).

${ }^{69}$ E. Hernández Aranda, un perfeccionamiento en la fabricación de cerillos, bujías de seguridad, 1885-86, AGN: Patentes y Marcas, caja 28, exp. 1263, fol. 1.

70 P. Parra, 'The general character of the positive method', in Nuevo sistema de lógica inductiva y deductiva (Mexico City, 1903), 225.

71 E. Hernández Aranda, un perfeccionamiento en la fabricación de cerillos, bujías de seguridad, 1885-86, AGN: Patentes y Marcas, caja 28, exp. 1263, fol. 17.

72 F. Tadeo Linder, fabricación de cerillos, fósforos y yesca de seguridad, 27 Nov. 1858, AGN: Patentes y Marcas, caja 5, exp. 369.

73 A. Martínez Urista, un extinguidor de incendios, 28 Dec. 1910, AGN: Patentes y Marcas, leg. 308, exp. 33, fol. 1 . 
last two decades of the nineteenth century, when hygienists awarded the capital the dubious honour of being the most unsanitary city in the world. ${ }^{74}$ Embracing the public hygiene recommendations of physicians and miasma theorists, inventors designed what they regarded as healthy ways to prevent fires. This effort included redesigning matches in attempts to make them less harmful and malodorous, something that consumed the time and energy of many inventors throughout the country. Patent applications, matchbox labels and newspaper advertisements praised safety matches that protected health, ${ }^{75}$ while match vendors claimed that they only sold healthy matches, ones that blessed customers with the gift of hygiene. ${ }^{76}$ Inventor E.M. Arzac asserted that he never used toxins to coat his matches, making them completely harmless to users' health. ${ }^{77}$ Until the advent of the safety match, matchsticks had been coated with yellow or white phosphorus, a dangerous chemical that posed a serious risk to workers in match factories and to anyone who lit matches on a regular basis. Employees at match factories often developed phossy jaw (the necrosis and decay of the jawbone), which caused severe pain, irreversibly deformed the faces of its victims, and made if difficult, if not impossible, to chew food. This disease afflicted workers throughout the world. ${ }^{78}$ After extensive toxicology investigations surrounding phosphorous poisoning in match factories, the US Bureau of Labor passed the White Phosphorous Match Act of 1913, which prohibited the manufacture and sale of matches coated with this chemical. ${ }^{79}$ Long before the implementation of phosphorus regulations in the United States, Mexican inventors understood the need to change match production practices because consumers demanded healthy alternatives to ordinary matches. ${ }^{80}$

Urban spatial factors also determined the types of inventions people deemed necessary for the capital. Announcing fires by ringing the nearest church bell caused problems in a growing city. First, it delayed response time because a witness had to run to the nearest church, ring the bell, and

${ }^{74}$ C. Agostoni, Monuments of Progress: Modernization and Public Health in Mexico City, 1876-1910 (Boulder, 2003), xii, 23; E. Wakild, 'Naturalizing modernity: urban parks, public gardens and drainage projects in porfirian Mexico City', Mexican Studies/Estudios Mexicanos, 23 (2007), 110.

75 Marketing ideas of health and healthiness became a common motif in advertisements, and Sunkist orange campaigns offer a clear example of this strategy; see D. Sackman, Orange Empire: California and the Fruits of Eden (Berkeley, 2005), 109.

76 D. Blumenkron, Mejora en la fabricación de cerillos fosfóricos, Oct. 1879, AGN: Patentes y Marcas, caja 14, exp. 848.

77 E.M. Arzac to the Ciudadano Secretario de Fomento Colonización Industria y Comercio, 1 Feb. 1886, AGN: Patentes y Marcas, caja 28, exp. 1263, fol. 23.

78 A. Rousscav y L. Chaubet. Fabricación de fósforos y cerillos inofensivos, 1858-59, AGN: Patentes y Marcas, caja 4, exp. 366, fol. 1; C. Clark, Radium Girls: Women and Industrial Health Reform, 1910-1935 (Chapel Hill, 1997).

79 B. Sicherman, Alice Hamilton: A Life in Letters (Cambridge, MA, 1984), 155-6.

80 Melosi, The Sanitary City, 17-42; L. Hill, The Chicago River: A Natural and Unnatural History (Chicago, 2000), 112; J. Sze, Noxious New York: The Racial Politics of Urban Health and Environmental Justice (Cambridge, 2007), 32-3. 
hope that enough people heard the call for help. Second, bells rang nonstop in Mexico to celebrate saints' days, to start mass and to announce the coming of religious processions. The message from the church bells often became blurred and knowing whether or not a bell rang to announce a church activity or in response to a fire meant that some residents inadvertently ignored desperate calls for help. This highly inefficient and slow method eventually became replaced in 1888 when the fire station received its first telephone, allowing firemen to hurry to the scene of the fire, even if the fire occurred on the other side of the capital. Yet again, this meant that someone had to witness the fire and run to the nearest telephone (in 1888 it was far easier to find a church than a telephone). Unlike the noisy and ineffective public ringing of church bells, the use of the telephone to call the fire department ensured that only the professional fire brigade received information about the burning building.

In an effort to alert the public of an impending disaster, inventors created appliances that immediately warned people that a fire had begun. Some automatic alarm systems, like the one invented by Francisco E. Oviedo and then improved upon after his death by his wife Matilde Rábago Viuda de Oviedo, ${ }^{81}$ alerted the household of a fire in the first moments that it ignited, making it easier to smother flames before they grew out of control. Other alarm systems took it a step further by including automatic sprinklers. The first of these locally invented apparatuses came from Miguel Laimón, an electrical engineer from the capital. He constructed a thin metal box full of liquid carbonic acid, which could be installed in any room, regardless of its size. The flames heated the metal box and sent a current from the heated metal to the copper wiring, thus releasing a valve and dropping the liquid on top of the flames. ${ }^{82}$ Mexico City electrician Guillermo Taverner improved upon the Laimón model by adding an alarm, but his newer system could only be installed in buildings with indoor plumbing, effectively limiting its consumer appeal..$^{83}$ The Taverner Automatic Extinguisher and Alarm contained a series of tubes with holes that could shoot out water in all directions to smother flames. When the temperature in a room rose to a particular point mercury crept up the glass wall of the thermometer and triggered an electrical current to make a bell ring furiously. Once the bell started to ring, the electrical current continued along the wire and opened the valves that connected the building's water pipes to the tubes in the sprinkler system. Water rushed into the tubes of the Taverner automatic extinguisher and sprayed out the holes and onto the flames. These inventors used technology to confront the problems of

${ }^{81}$ M. Rábago Vda. de Ovieda, Un aparato anunciador de incendios, 16 Feb. 1911, AGN: Patentes y Marcas, leg. 308, exp. 28, fols. 1-2.

82 M. Laimón, un auto anunciador de incendio, 23 Apr. 1907, AGN: Patentes y Marcas, leg. 308, exp. 16, fols. 1-2.

83 G. Taverner, Alarma y auto-extinguidor de incendios 'Taverner', 1 Sep. 1909, AGN: Patentes y Marcas, leg. 308, exp. 26, fols. 1-7. 
living in a growing city where a house could become completely consumed by flames before professional help arrived.

Despite the option to purchase automatic alarms, General Felix Díaz, the nephew of the president and the inspector general in charge of the police and fire departments, complained to a US reporter that that the fire stations were severely underequipped, lacking an alarm system to alert the men to fires that erupted across the city. ${ }^{84}$ This statement shows how the invention of a technology did not always correspond to its adoption and use. Nonetheless, inventors' efforts to create specific technologies show the particular areas that inventors thought needed improvement. During the first decade of the twentieth century, cinemas had become a profitable business, but theatres frequently experienced horrific fires, especially in overheated film reel rooms. Entrepreneurs made protection a business, seeing theatres as opportunities to profit from serious fire risks. Mexico City businessman Carlos Villegas designed a machine to extinguish flames instantly when nitrate film caught fire. At the first sign of fire in the projector room, an employee could pull on a cord attached to a holding tank that would drop water directly on top of the flames. ${ }^{85}$ Electrician Ricardo Rojas built off of Villegas' original innovation. In his invention, he added a heat-triggered automatic sprinkler, which connected to lights within the theatre. If a fire erupted, the house lights flashed to alert audience members to the fire. ${ }^{86}$

If the engineers' craft was most visible in public venues and on street corners, entrepreneurs' products and services could be seen most prominently inside the businesses of capital residents. Regardless of the home-grown attempts at fire-safety innovation, most of the devices that were adopted in Mexico came from foreign companies. City council records from 1884 detail the purchase of 10 boxes of fire grenades from a New York-based company, even though several Mexican inventors had registered similar models with the patenting office. ${ }^{87}$ Newspaper advertisements show that the only commercially available fire-safety devices came from abroad. ${ }^{88}$ Sanborn fire maps offer a window into the private lives of residents by opening up buildings and peeking inside to see what safety precautions they purchased for their protection. While alarms and sprinklers did not appear in many homes, some larger businesses,

84 'Organization of the police department in Mexico', Overland Monthly: The Awakening of Mexico Centenary of the Republic, 56 (1910), 114-18.

85 C. Villegas, 6 Dec. 2007, AGN: Patentes y Marcas, leg. 308, exp. 18, fols. 1-2.

${ }^{86}$ R. Rojas, un aparato automático contra incendio de películas cinematográficas, 29 Jun. 1912, AGN: Patentes y Marcas, leg. 308, exp. 35, fols. 1-3.

87 J. Septien, un medio para extinguir incendios, 20 Aug. 1884, AGN: Patentes y Marcas, caja 25, exp. 1147, fols. 1-9; Wadsworth, Martínez, Longman, Unas granadas de mano para extinguir incendios, 2 Sep. 1884, AGN: Patentes y Marcas, caja 32, exp. 1146, fols. 8-16.

88 'La mejor protección absolutamente contra el fuego', El Siglo Diez y Nueve (26 Dec. 1874), 4; 'Minimax, el rey de los extinguidores de incendios', El Imparcial (25 Sep. 1908). 
such as La Concordia Clothing Company, invested in these technologies. ${ }^{89}$ The maps help to answer the question about whether or not technologies were adopted and used in the city. Surprisingly, businesses purchased an array of extinguishers from different companies. While owners from La Tablacera and El Buen Tono cigarette factories purchased Worthington pumps from New York, owners of the Zolly Hermano's Hat manufacturing workshop preferred the Triplex brand power pump from Chicago to guard the felting machine. In regards to handheld chemical extinguishers, La Victoria Woolen Mill used Miller Chemical extinguishers of Chicago, the Mexican Gas \& Electric Light Company imported Babcock handheld extinguishers from Chicago and La Gran Union Distillery favoured the New Peoria Chemical Fire Extinguishers from Peoria, Illinois. In 1905, only one company, the Iron Works \& Foundry, still used glass hand grenades. Limiting their inventories of extinguishers and sprinklers to the biggest factories, the Sanborn fire maps show that business owners preferred to import safety devices, rather than purchase one of the many Mexican-made products.

Even if the majority of the population could not afford to purchase these new technologies, fire insurance maps indicate that fire control and prevention were a visible part of the city. Each layer of the built environment had been imprinted with signs of fire. Beneath the city, in the soft lakebed soil, sat water pipes full of rushing water from streams and aqueducts outside of the capital. Designed to provide water to the residents, the pipes connected to hydrants and cisterns, which became essential to extinguish fires. The crowded avenues and plazas bore more signs of safety efforts: fire departments, fire engines, hoses and ladders. Inside the buildings, hidden from the street, safety appliances such as extinguishers, pumps and alarms protected the building's inhabitants. Additionally, rooftops contained pumps and cisterns that could use gravity to propel hundreds of gallons of water down below almost instantaneously. Fire technologies altered the way the city looked and functioned.

\section{Conclusions}

Tormented by bouts of fires, the hazardous city prompted trained and non-trained residents to experiment with machinery and chemicals to prevent and control fires. On the one hand, these men and women thought that protecting the capital represented a national duty and promoted the ideal of a safe and industrious city as a way to improve their patent applications or receive a commission from the municipal government. On the other hand, both engineers and inventors understood fires as

89 'City of Mexico', Sanborn Fire Insurance Maps, 1905, Perry-Castañeda Library Map Collection, Sanborn Maps of Mexico, University of Texas Libraries. 
business opportunities and tried to profit from safety inventions. In the late nineteenth century, in Mexico as well as other Latin American nations, architects and engineers earned positions of power in cites and they became recognized as experts in urban planning and safety. ${ }^{90}$ Their university training in Mexico and abroad made politicians, firemen and residents from around the country look to them for advice about how to prevent and combat fires. Academic training gave engineers technical expertise, social prestige and political influence. This, combined with real-life experience with the hazards of fire, led to the emergence of a new group of lay inventors. The professionalization of engineers and the emphasis on technological development inspired lay inventors and small-scale entrepreneurs to build machines for human benefit. In an era when people exchanged ideas on an international scale and when science and technology promised to improve social life, inventors and engineers offered to bring these ideals to Mexico City. Some succeeded, others did not, but their eagerness to improve safety shows how fire risks had become a common occurrence in city life in an era of rapid urban growth and development.

90 J.E. Hardoy, 'Theory and practice of urban planning in Europe, 1850-1930: its transfer to Latin America', in R.M. Morse (ed.), Rethinking the Latin American City (Washington, DC, 1992), 23. 